Original Research Paper

\title{
Molecular Approach to Identify Gobioid Fishes, "Nike" and "Hundala" (Local Name), from Gorontalo Waters, Indonesia
}

\author{
Abdul Hafidz Olii, Femy M. Sahami, Sri Nuryatin Hamzah and Nuralim Pasisingi \\ Department of Aquatic Resources Management, Faculty of Fisheries and Marine Science, \\ Gorontalo State University, Gorontalo City, Indonesia
}

Article history

Received: 11-09-2018

Revised: 3-01-2019

Accepted: 08-02-2019

Corresponding Author:

Abdul Hafidz Olii

Department of Aquatic

Resources Management, Faculty of Fisheries and Marine Science,

Gorontalo State University,

Gorontalo City, Indonesia

Email: oliihafidz@gmail.com

\begin{abstract}
Data of the species scientific name is required to study biodiversity and conservation of local fish species. Nike and hundala are the local names for fish found in Gorontalo whose scientific names are unknown and recognized by local people as two different species of fish. This study aims to identify the genetic and species of nike and hundala fish. Nike and hundala specimens were collected using a fish net from the estuary of Gorontalo Bay and Bone River, Gorontalo, Indonesia in April 2018. Molecular analysis of fish over sequencing methods shows that nike and hundala at Gorontalo waters are alleged as Sicyopterus longifilis.
\end{abstract}

Keywords: Gorontalo, Local Fish Hundala, Nike, Sicyopterus longifilis, Sicyopterus pugnans

\section{Introduction}

Nike and hundala are the local names of fish found in the waters of Gorontalo, Indonesia where the scientific name of these two types of fish is not known. Biological and ecological information on both types of these species is also not yet available. These two types of fish are endemic in Gorontalo and have not been determined scientifically. A comprehensive scientific study of nike and hundala fish in Gorontalo waters is required to facilitate further research, especially those related to bioecology in supporting the management and conservation of fish species in the world.

Nike is the local name of small fish found in the waters of the sea and estuary of Bone River, Gorontalo, Indonesia (Olii et al., 2017). Nike fish in Gorontalo waters will only appear in a few days at the end of the lunar phase (Pasisingi and Abdullah, 2018) and move from the sea towards the estuary and disappear and then reappear in the final few days of the next phase of the month and at the beginning of the new month. Nike fish is thought to have transformed into adult fish during the time of movement to reach the river so that its form is no longer recognized.

Morphologically, hundala fish exhibit features that similar to nike. This led to the notion that the hundala fish was an adult nike that had reached the river to spawn. However, this hypothesis has not been scientifically proven. Therefore, it is necessary to study the comparison of nike and hundala. This study aims to identify the species of nike and hundala fish with a molecular approach.

\section{Materials and Methods}

\section{Sampling}

Nike and hundala specimens were collected from the estuary of Gorontalo Bay ( $\mathrm{N} 00^{\circ} 30.305^{\prime}$ and $\mathrm{E}$

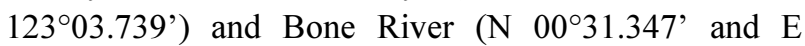
$123^{\circ} 04.358^{\prime}$ ) in Gorontalo waters, Indonesia (Fig. 1) in April 2018. Samples were caught using a fish net.

\section{Molecular Analysis}

Genomic DNA was isolated from the muscle tissue for sequencing method using the Genomic DNA mini kit (plant), Geneaid. Sequencing target was the cytochrome c oxidase subunit I (COI) gene due to DNA barcoding based on a fragment of the COI gene in the mitochondrial genome is widely applied in species identification and biodiversity studies (Bingpeng et al., 2018). The COI gene is recommended as the standard barcoding marker for most animals (Renxie et al., 2018). Based on COI barcoding, high rates of species-level identification are well documented in many animal species, for instance, $95.27 \%$ for numerous northwestern pacific mollusks (Sun et al., 2016) and $98 \%$ for marine fishes (Ward, 2009). In addition, many studies have shown that intraspecific variation of COI barcodes is generally pretty small and clearly discriminable from interspecific variation (Hubert et al., 2008; Steinke et al., 2009; Ward et al., 2009; Bucklin et al., 2011). 


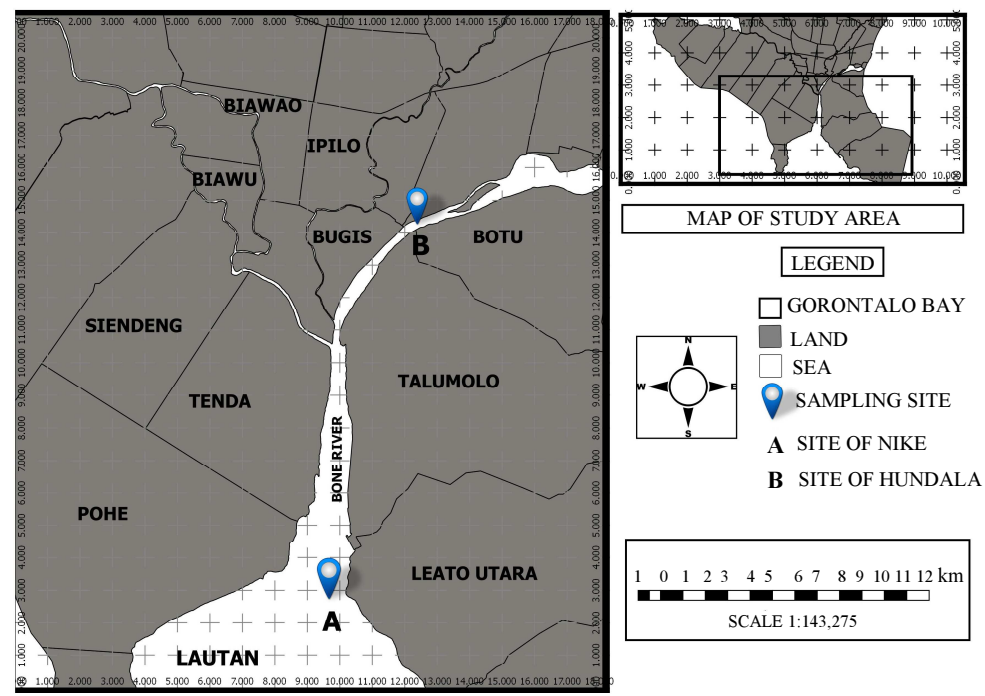

Fig. 1: Sampling sites of nike and hundala in Gorontalo Waters

The COI gene was amplified with primers Fish BCL: 5' TCAACYAATCAYAAAGATATYGGCAC-3' and Fish BCH: 5'- ACTTCYGGGTGRCCRAARAATCA-3' (Baldwin et al., 2008) in a $50-\mu \mathrm{L}$ volume with $18 \mu \mathrm{L}$ ddH2O, $2.5 \mu \mathrm{L}$ of Fish BCL $(10 \mu \mathrm{M}), 2.5 \mu \mathrm{L}$ of Fish BCH $(10 \mu \mathrm{M}), 1.0$ unit of DMSO, $25 \mu \mathrm{L}$ of Go Taq Green PCR Mix $2 X$ and $2 \mu \mathrm{L}$ of DNA template. The PCR conditions were pre-denaturation at $80^{\circ} \mathrm{C}$ for $10 \mathrm{~s}$ and initial denaturation at $94^{\circ} \mathrm{C}$ for $5 \mathrm{~min}$, followed by 40 cycles of $30 \mathrm{~s}$ at $94^{\circ} \mathrm{C}, 30 \mathrm{~s}$ at $50^{\circ} \mathrm{C}, 45 \mathrm{~s}$ at $72^{\circ} \mathrm{C}$ and the final extension at $72^{\circ} \mathrm{C}$ for $7 \mathrm{~min}$. The PCR products were visualized on $15 \%$ agarose gel.

The sequencing process was carried out using the Sanger Termination Dideoxy Method. The sequencing process was carried out by 1st Base, Malaysia, through PT. Genetic Science. The nucleotide sequence from DNA sequencing was carried out by CONTIG using the BioEdit application with manual editing and pruning during the alignment process. The Alignment data obtained was then matched with the data available on the Genbank, namely Barcode of Life Data (BOLD) system and National Center for Biotechnology Information (NCBI).

A phylogenetic tree was arranged by aligning DNA sequences of nike and hundala fish identified with several DNA sequences of species in the same family. The tree was made using the Maximum Likelihood Method with 1000 bootstraps. DNA sequences and phylogenetic tree compilation are aligned using MEGA 6.0 application with default settings.

\section{Results}

\section{Genetic Identification of Nike and Hundala Fish}

Genetic identification carried out to confirm genetics of nike and hundala fish in Bone River, Gorontalo.

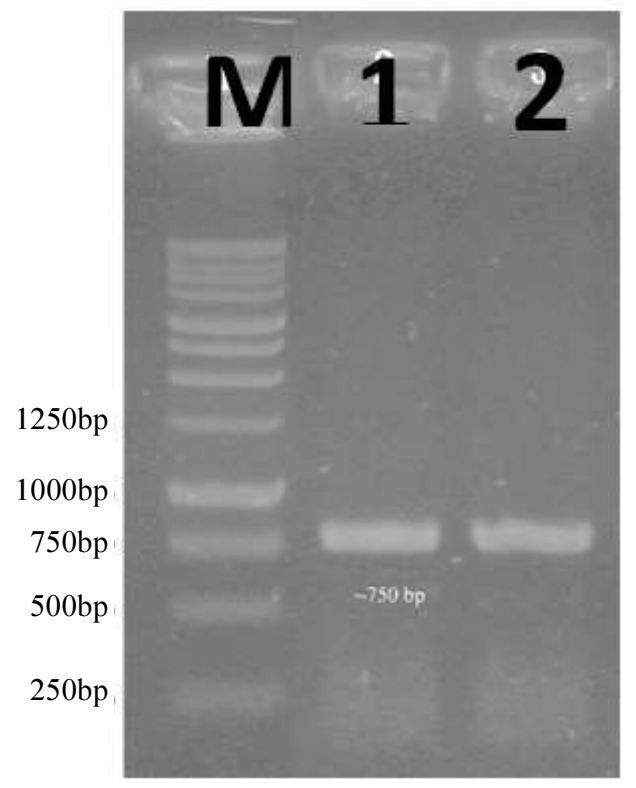

Fig. 2: Electrophoresis results of nike and hundala DNA (M= DNA ladder $100 \mathrm{bp} ; 1=$ Hundala; $2=$ Nike)

Electrophoresis of mitochondrial DNA COI genes of nike and hundala fish is shown in Fig. 2, with amplicon lengths of $\sim 600-700 \mathrm{bp}$.

CONTIG results of nucleotide sequencing of nike and hundala using Bioedit software were subsequently identified based on the BOLD system database on the www.boldsystems.org website, by selecting the database Species Level Barcode Records (3,170,080 Sequences/ 192,274 Species/77,605 Interim Species). The results of genetic identification comparison of nike and hundala to fish sequences in BOLD and NCBI database are presented in Table 1 and 2 respectively. 
Nike and hundala are thought to be the same species as Sicyopterus longifilis. This is as based on BOLD database (Table 1) they have the highest similarity to Sicyopterus longifilis with the number of $100 \%$ and $99.68 \%$ consecutively. Whereas, according to NCBI database, the highest similarity value of merely $99 \%$ is indicated by nike and hundala fish as Sicyopterus pugnans (Table 2).

The phylogenetic tree also aligns some of the genetics of fish in the same genus available in BOLD which are also found in other areas (Fig. 3). Nike and hundala species have a very close relationship with the species $S$. pugnans caught in French, Polynesia.

Table 1: The comparison of nike and hundala sequences with BOLD fish database

\begin{tabular}{lllll}
\hline No & Specimens & Species & Similarity & Data Status \\
\hline 1 & Nike & Sicyopterus longifilis & $100 \%$ & Private \\
2 & & S. longifilis & $100 \%$ & Private \\
3 & & S. longifilis & $100 \%$ & Private \\
4 & & S. longifilis & $100 \%$ & Private \\
5 & \multirow{2}{*}{ Sundala } & S. longifilis & $100 \%$ & Private \\
1 & S. longifilis & $99.68 \%$ & Private \\
2 & & S. longifilis & $99.52 \%$ & Private \\
3 & S. longifilis & $99.52 \%$ & Private \\
4 & S. longifilis & $99.52 \%$ & Private \\
5 & S. longifilis & $99.52 \%$ & Private \\
\hline
\end{tabular}

Table 2: The comparison of nike and hundala sequences with NCBI fish database

\begin{tabular}{lllll}
\hline & & Accession & \\
No & Specimens & Species & Number & Identity \\
\hline 1 & Nike & Sicyopterus pugnans & KJ202204.1 & $99 \%$ \\
2 & & S. pugnans & KF668861.1 & $96 \%$ \\
3 & & S. pugnans & HQ639045.1 & $95 \%$ \\
4 & & S. pugnans & HQ639044.1 & $95 \%$ \\
5 & & S. pugnans & JQ432155.1 & $95 \%$ \\
1 & Hundala & S. pugnans & KJ202204.1 & $99 \%$ \\
2 & & S. pugnans & KF668861.1 & $96 \%$ \\
3 & & S. pugnans & HQ639045.1 & $95 \%$ \\
4 & & S. pugnans & HQ639044.1 & $95 \%$ \\
5 & & S. pugnans & JQ432155.1 & $96 \%$ \\
\hline
\end{tabular}

Due to $S$. longifilis sequence data in BOLD database is still private and has not been permitted to be accessed, the study used fish sequences available in NCBI database to display nike and hundala fish relations to the other gobiidae (Fig. 4).

Figure 4 shows that nike and hundala fish are obviously separated from $S$. pugnans. On the other hand, nike and hundala share the highest similarity to each other. Unfortunately, the location of S. longifilis among nike and hundala fish cannot be displayed on the phylogenetic tree since this species is not available in NCBI database. In this case, although a more comprehensive analysis is needed to convince that they are characterized as the same fish, this allegation is still possible due to their nucleotide variation occurs only three times with base sequences of 97, 391 and 454 from the edited sequence along $650 \mathrm{bp}$. As a result, the small p-distance of 0.0046 between the two samples supports that these two samples were the same species.

\section{Morphological Characteristics of Nike and Hundala Fish}

Nike and hundala are considered fish that have different stages of life. Nike is a juvenile while hundala is an adult stadium (Fig. 5), yet in this study, no detail morphological identification of nike and hundala species was carried out.

The morphological characteristic of nike is shown by the small body size which only reaches $3 \mathrm{~cm}$ and the body color is still transparent. The body has no scales, incomplete fins and an undeveloped mouth.

Hundala morphology showed a long body size reaching $6.5 \mathrm{~cm}$ compared to nike. Hundala has the dark body color and there were grayish spots on the dorsal part. Its body was scaly and the fin was complete with the blonde caudal fin color, flatted head shape, and the inferior mouth has developed perfectly.

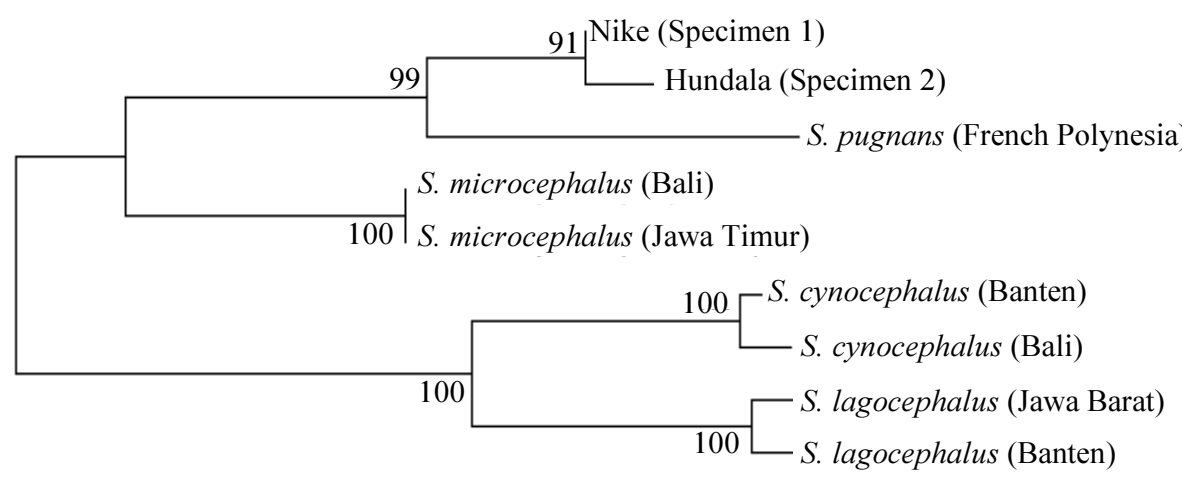

0.01

Fig. 3: Phylogenetic trees of nike and hundala compared to species found from other areas available in BOLD 
Abdul Hafidz Olii et al. / OnLine Journal of Biological Sciences 2019, 19 (1): 51.56

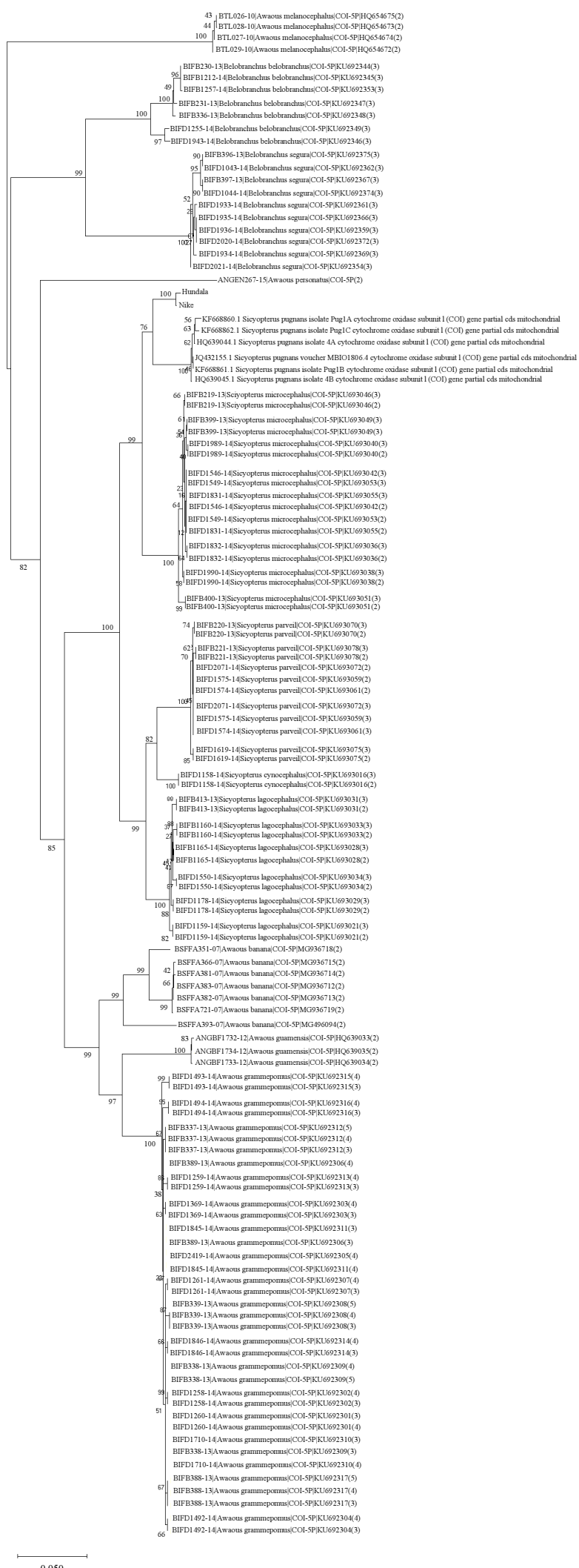

Fig. 4: Phylogenetic tree of nike and hundala compared to some gobiidae species available in NCBI 


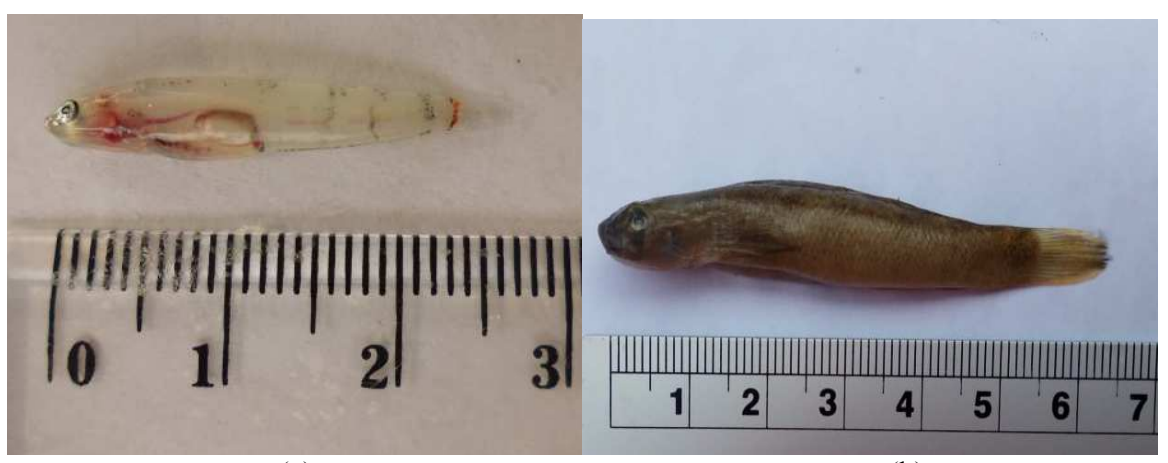

(a)

(b)

Fig. 5: Specimens of (a) nike and (b) hundala from Gorontalo Waters

\section{Discussion}

This study shows that nike and hundala fish in Gorontalo waters are apparently as Sicyopterus longifilis species which is a freshwater fish type from the gobioid group based on their highest sequence similarity to $S$. longifilis in BOLD system. The species of $S$. longifilis originates from the Sicydiinae family (Wang et al., 2001). Lord et al. (2010) stated that fresh water of the Pacific region is inhabited by Gobiidae (Sicydiinae) species with a specific life cycle adapted to the insular amphidromous called as the environment (Keith, 2003). In this life cycle, newly hatched fish drift downstream to the ocean, recruit back to stream mouths as juveniles and then migrate upstream to live as adults (Luton et al., 2005).

The results of this study indicate that nike fish is the local designation of the Gorontalo community for juvenile phase, while the adult is hundala. Both are alleged as Sicyopterus longifilis. Keith et al. (2008) found that the morphological transformation of Sicyopterus lagocephalus between hatching and the adult phase is composed of two larval stages (L1, L2). In an adult stage, coloration is typical of sexual dimorphism. The mouth is inferior. The caudal fin distal border is rounded $(\%$ $\mathrm{C}$ superior to $100 \%$ ). Adults are found in the lower, medium and upper courses of the river. Yamasaki et al. (2007) described briefly the developmental stages of another Siclydiine Gobiidae, a Stiphodon, using the terms "pelagic larvae", "settled larvae", "juvenile" and "adult".

Although scientific studies of $S$. longifilis species in Gorontalo waters are not yet available, Keith et al. (2011) described five new species of Sicyopterus, freshwater gobies, are described in Papua New Guinea and Papua Province, Indonesia. They differ from other species belonging to the genus by the combination of characters including the upper lip morphology, the second dorsal fin, the scales in the lateral, pre-dorsal, transverse back, transverse forward and zigzag series, sexual dimorphism and live colors.

\section{Conclusion}

From this study, we come to the conclusion that nike and hundala fish supposedly as Sicyopterus longifilis which are considered as species available in the Bone River and the estuary of Gorontalo Bay. Furthermore, a more comprehensive analysis of other divergent gene sequences is needed to convince this species characterization.

\section{Acknowledgment}

We wish to thank the staff of Fisheries and Marine Science Faculty Laboratory, Gorontalo State University for technical help.

\section{Funding Information}

This project is funding by the Directorate of Research and Development, Ministry of Research, Technology and Higher Education of Republic Indonesia.

\section{Author's Contributions}

Abdul Hafidz Olii: Coordinated the implementation of research work, conducted research, compiled the literary review, analyzed and interpreted the study findings, drew conclusions, contributed manuscript preparation and revisions

Femy M. Sahami: Designed the research plan, organized the study, conducted research, and contributed to result analysis and the writing manuscript.

Sri Nuryatin Hamzah: Conducted research, compiled the literary review, analyzed and interpreted the results, contributed manuscript revisions.

Nuralim Pasisingi: Conducted research, contributed manuscript revisions

\section{Ethics}

This article is original and contains unpublished material. The corresponding author confirms that all of the other authors have read and approved the manuscript and there are no ethical issues involved 


\section{References}

Bingpeng, X., L. Heshan, Z. Zhilan, W. Chunguang and W. Yanguo et al., 2018. DNA barcoding for identification of fish species in the Taiwan Strait. PLoS ONE, 13: 1-13. e0198109.

DOI: 10.1371/journal.pone.0198109

Bucklin, A., D. Steinke and L. Blanco-Bercial, 2011. DNA barcoding of marine metazoa. Annual Rev. Marine Sci., 3: 471-508.

DOI: 10.1146/annurev-marine-120308-080950

Hubert, N., R. Hanner, E. Holm, N.E. Mandrak and E. Taylor, 2008 Identifying Canadian freshwater fishes through DNA barcodes. PLoS One, 3: 1-8 e2490. DOI: 10.1371/journal.pone.0002490

Keith, P., 2003. Biology and ecology of amphidromous gobiidae in the Indo-Pacific and the Caribbean Regions. J. Fish Biol., 63: 831-847.

Keith, P., R.K. Hadiaty and C. Lord, 2011. Five new species of Sicyopterus (Gobioidei: Sicydiinae) from Papua New Guinea and Papua. Cybium, 35: 299-318.

Keith, P., T.B. Hoareau, C. Lord, O. Ah-Yane and G. Gimonneau et al., 2008. Characterisation of postlarval to juvenile stages, metamorphosis and recruitment of an amphidromous goby, Sicyopterus lagocephalus (Pallas) (Teleostei: Gobiidae: Sicydiinae). Marine Freshwater Res., 59: 876-889.

Lord, C., C. Brun, M. Hautecœur and P. Keith, 2010. Insights on endemism: comparison of the duration of the marine larval phase estimated by otolith microstructural analysis of three amphidromous Sicyopterus species (Gobioidei: Sicydiinae) from Vanuatu and New Caledonia. Ecology Freshwater Fish, 19: 26-3. DOI: $10.1111 / \mathrm{j} .1600-0633.2009 .00386 . x$

Luton, C.D., A.M.D. Brasher, D.C. Durkin and P. Little, 2005. Larval drift of amphidromous shrimp and gobies on the island of Oahu, Hawai'i. Micronesica, 38: $1-16$.
Olii, A.H., F.M. Sahami, S.N. Hamzah and N. Pasisingi, 2017. Preliminary findings on distribution pattern of larvae of nike fish (Awaous sp.) in the estuary of Bone River, Gorontalo Province, Indonesia. AACL Bioflux, 10: 1110-1118.

Pasisingi, N. and S. Abdullah, 2018. (in Indonesian) Pattern of nike fish (Gobiidae) occurrence in the Gorontalo Bay, Indonesia. Depik, 7: 111-118.

Renxie, W., Z. Haoran, L. Jing, N. Sufang and X. Yao et al., 2018. DNA barcoding of the family Sparidae along the coast of China and revelation of potential cryptic diversity in the Indo West Pacific oceans based on COI and 16S rRNA genes. J. Oceanology Limnology, 36: 1753-1770. DOI: $10.1007 / \mathrm{s} 00343-018-7214-6$

Steinke, D., T.S. Zemlak and P.D.N. Hebert, 2009 Barcoding Nemo: DNA-based identification for the marine ornamental fish trade. PLoS One, 4: 1-5 e6300. DOI: 10.1371/journal.pone.0006300

Sun, S.E., Q. Li, L.F. Kong, H. Yu and X. D. Zheng et al., 2016. DNA barcoding reveal patterns of species diversity among northwestern pacific molluscs. Science Report, 6: 1-17. DOI: 10.1038/srep33367

Wang, H., M. Tsai, J. Dean and S. Lee, 2001. Molecular phylogeny of gobioid fishes (perciformes: gobioidei) based on mitochondrial 12s rRNA sequences. Molecular Phylogenetics Evolution, 20: 390-408. DOI: 10.1006/mpev.2001.0957

Ward, R.D., 2009. DNA barcode divergence among species and genera of birds and fishes. Molecular Ecology Resources, 9: 1077-1085. DOI:10.1111/j.1755-0998.2009.02541.x

Ward, R.D., R. Hanner and P.D.N. Hebert, 2009. The campaign to DNA barcode all fishes. J. Fish Biology, 74: 329-356. DOI: $10.1111 / \mathrm{j} .1095-8649.2008 .02080 . \mathrm{x}$

Yamasaki, N., K. Maeda and K. Tachihara, 2007. Pelagic larval duration and morphology at recruitment of Stiphodon percnopterygionus (Gobiidae: Sicydiinae). Raffles Bulletin Zoology Supplement, 14: 209-214. 